\title{
An Evaluation of Performance of Teacher Trainees in Initial Teacher Education: A Case Study
}

\author{
Kurukulaarachchi, V.K.N * \#01 \\ Senior Lecturer, Faculty of Humanities and Education, CINEC Campus, \\ Millennium Drive, IT Park, Malabe, Sri Lanka \\ *veronica. kurukulaarachchi@cinec.edu
}

\begin{abstract}
Privatization and internationalization of education in Sri Lanka has created a demand for more trained teachers, unlocked teacher education to private teacher training institutes in Sri Lanka. To maintain the quality of the programme, tertiary authority registration of the relevant programme is required for the institute. Objectives of the study are to assess the current levels of performance of the trainee teachers, to investigate the challenges and issues faced by the institute and to examine the impact of the tertiary authority registration process on Teacher Education Diplomas. The sample size of this qualitative/quantitative research is 90 teacher trainees. Data collection methods were questionnaire, key informant interviews and documentary analysis. Study found that $63 \%$ trainees believed their performance is very good while $29 \%$ and $8 \%$ believed their performance is good and averaged respectively. However, there is no significant relationship between education and performance. Although the tertiary authority uses online platforms, the findings of the study revealed that the institute faces constant challenges due to procrastination practices and bureaucratic procedures. Furthermore, the institute struggles with the supervision of teaching practice. $87 \%$ trainees stated that registration of their diploma at the tertiary authority motivated them to enroll at the institute. yet the registration of the diplomas at the tertiary authority had on low impact on the learning teaching process.
\end{abstract}

Key Words: Performance, Tertiary authority, Teacher education, Teacher trainees

\section{INTRODUCTION}

Teaching is the noblest profession and they transform students' behaviour with knowledge attitudes and skills. On the other hand, students' performance depends on teachers' performance. Therefore, teacher education is very vital since the teachers mould the future generation. Rahaman et al (2011) stated that "teacher education is the integral part of the education system, has greatly expanded and will expand further to cater to the fast emerging needs of the country" (p.150).According to United Nations Educational, Scientific and Cultural Organization (UNESCO), Teacher Education is formal training for teachers who can be in pre- service or in service and which is intended to furnish them with knowledge, attitude, beahaviour and skills requisite for teaching at the relevant level. There is a formal Teacher Education system in Sri Lanka specifically with reference to Government higher education policy. State sector teacher education starts at G.C.E Advanced Level or at National
College of Education or University level. However, presently privatization of education is inevitable. Noticeably, this has an impact on teacher education as well and there is increasing number of private higher education institutes who conduct Teacher Education diplomas. Higher education institutes at present concentrate more on Teacher Education at tertiary and vocational level which will lead to employment or job opportunities. According to Edirisinghe (2016) tertiary and vocational training helps trainees acquire skills and prepare them for employment. Tertiary education can be defined as third level or post secondary education after completion of secondary education at school and this consists of academic and vocational education. In order to obtain the state recognition, the higher education institutes need to be registered in Tertiary Vocational and Education Commission (TVEC) in Sri Lanka. Conversely, without TVEC registration neither relevant institute nor Teacher Education diploma will be recognized by the students, their parents and all other relevant stakeholders. TVEC maintains the nationally recognized policy for awarding TVEC certificates and development and maintenance of academic and training standards for institutes, agencies and all other Tertiary Vocational and Education Training (TVET) providers (Ministry of Skills Development and Vocational Training 2019).

This study is carried out in one of the well-known Higher Education Institute/Non-state universities in Sri Lanka. However, in order to achieve the research objectives headquarters of the institute will be considered and the effectiveness of teacher education diplomas which are registered under the TVEC are focused here. Effects of the registration of TVEC on the teacher education diplomas, current procedures are also discussed.

\section{B. PROBLEM STATEMENT}

Due to privatization and internationalization of education in Sri Lanka, it demands more trained teachers. Limited numbers of teacher trainees are recruited in State teacher training colleges or National College of Education with all three qualified subjects in Advanced level examination. Therefore, the need or the opportunity has been unlocked for privately owned teacher training academies or institutes. Wettawa (2016) claimed that Sri Lanka identifies private education as a crucial driver for economic growth and option as a fundamental element of democracy. Hence, there are teacher education programmes booming in higher education sector. In order to maintain the quality, the higher education institutes should register their organization and programmes with the TVEC and maintain the

The CINEC journal 2020 
entry level qualification for teacher trainees or prospective teachers. Nevertheless, in order to achieve the business objectives higher education institutes, need to attract more trainees therefore, like any other private institute $\mathrm{ABC}$ Higher Education Institute also maintains their flexible registration process specifically with regards to entry qualification of teacher trainee which will impact on quality of the teacher education. More often than not the institute is stressed to comply with three passes in Advanced level examination as a minimum entry qualification for teacher trainees. However, occasionally the institute is unable to comply with the at least two passes of Advanced level qualification since they must achieve the business objectives. According to Wheelahan (2014) qualifications for Vocational and Tertiary level teacher trainees could be varied depending on the level at which they are teaching. This means there is no consistency in their entry level qualification. Not only entry qualifications but also there are issues pertaining to teaching practice and supervision since there is no proper evaluation mechanism. According to Edirisinghe et al (2016), in fact, there is a lack of monitoring, evaluation and coordination system for TVET sector. Further institution entertains or at times struggles with the needs of the students including lame excuses especially in relation to teaching practice. Ultimately, these issues will lead to the quality of prospective teachers.

There were some studies carried out in relation to Teacher Education in Sri Lanaka with reference to state sector, Polgampala (2020) Lekamge (2018), National Education Commission (2016), Nanayakkara et al (2006), Johnson (2006) Dharmadasa et al (1996), Tatto et al (1993), Wewegama(n.d.). However no or least possible researches have been done in connection with Teacher Education in private institutes and TVEC registration pertaining to the said pogrammes. Hence, the researcher intends to find out levels of current performance of the trainee teachers and impact of TVEC registration process on Teacher Education diplomas since teachers act as a change agent and immensely contribute to the education system and high-quality workforce.

\section{A. SIGNIFICANCE OF THE STUDY}

The study intends to enhance the existing knowledge in the subject area of Teacher Education system. Though there is ample number of researches on the Teacher Education, there are only few researches in the Sri Lankan context. Further, even there are very few researches has been done particularly with regards to teacher education in privately owned Higher Education Institutes. Less researches have been conducted in Teacher Education and Non state universities in Sri Lanka. Therefore, current study realizes the empirical gap in the Sri Lankan context.

Previous studies have concerned more on identifying Teacher Education in State sector rather than the private sector. Throughout this study the research gap will be addressed as this is the study to assess the performance of teacher trainees and examine the impact of TVEC registration process on Teacher Education Diplomas in privately owned higher education institutes which can not be ignored as the privatization of education is unavoidable now. Moreover, research studies and textbooks on teacher education are not extensive. Therefore, this study will be a helpful reading material for students and researchers. The findings of this research will be of assistance to the future researchers to conduct their researches more successfully.

The findings of the study will help for the management of higher education institutes to formalize their registration process particularly with regards to entry qualifications, evaluation and monitoring of teaching practice, better coordination with TVEC and attract more trainee teachers and ultimately improve the quality of Teacher Education in private institutes.

\section{RESEARCH QUESTIONS}

1. What are the levels of current performance of the trainee teacher?

2. What are the challenges and issue faced by the institute in registration process?

3. What is the impact of the TVEC registration process on Teacher Education Diplomas?

\section{OBJECTIVES OF THE STUDY}

1. To assess the current levels performance of the trainee teacher.

2. To investigate the challenges and issue faced by the institute in registration process.

3. To examine the impact of the TVEC registration process on Teacher Education Diplomas.

\section{DATA AND METHODOLOGY}

The study can be considered as a survey research and quantitative data has been complemented with the qualitative data in the study. Simple random sample used to select the respondents. Population of Teacher trainees were 105 and the researcher has used random number method by assigned every teacher trainee a number and sample size of 90 randomly selected a subset of the population. Biographic details of the teacher trainees are their age range varied from 19 to 35 years old and they represent different areas of the county. Further their educational background differs from G.C.E. Advanced Level qualification to degree level. Data collection methods were questionnaire, key informant interviews and documentary analysis. Area of the study is one of the largest Higher Education Institutes which is also recognized as a one of the well-known non- state universities in Sri Lanka. Questionnaire consists of main sections on demographic characteristics, performance of the respondents.

Performances of the teacher trainees have measured according to the 5-point Likert scale. For the purpose of gathering data three key informant interviews have conducted with key stakeholders in the organization viz with the Head of the Department and Coordinator of the programme. Analysis of documents, informal discussions and secondary data has been used to collect more information. Secondary information is 
readily available information to use for the research. Therefore, relevant reports and documents in the institute, newspapers, articles, gazette, and minutes of meetings, internet and intranet have taken as secondary data. Response rate is hundred percent and Saunders et al suggested (2007 as cited in Jocelyne 2014) that the response rate of at least 90 per cent was considered as good rate.

\section{RESULTS}

According to the findings of the study, 69\% teacher trainees are female compared to male (31\%) trainees (figure 1). Majority of teacher trainees $(55 \%)$ are between age ranges of 18 to 23 years, $25 \%$ of teacher trainees are age range of $24-29,11 \%$ teacher trainees are $30-35$ of age range, $5 \%$ of teacher trainees are age range of $36-41$ (Figure 2). Study revealed the qualification levels of teacher trainees, namely, 69\% teacher trainees are Advanced Level partly or fully qualified, $26 \%$ diploma qualified, $1 \%$ degree qualified and 4\% Ordinary Level qualified (Figure 3). Thus 63\% trainees believed their performance is very good while $29 \%$ and $8 \%$ believed their performance is good and average respectively.

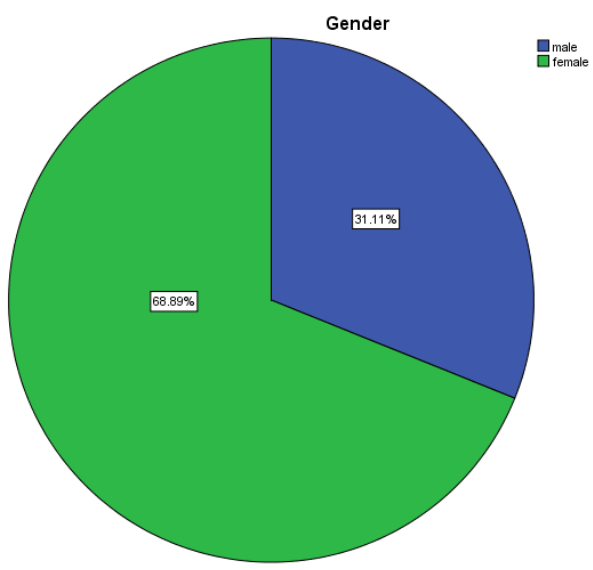

Figure 1: Gender Analysis

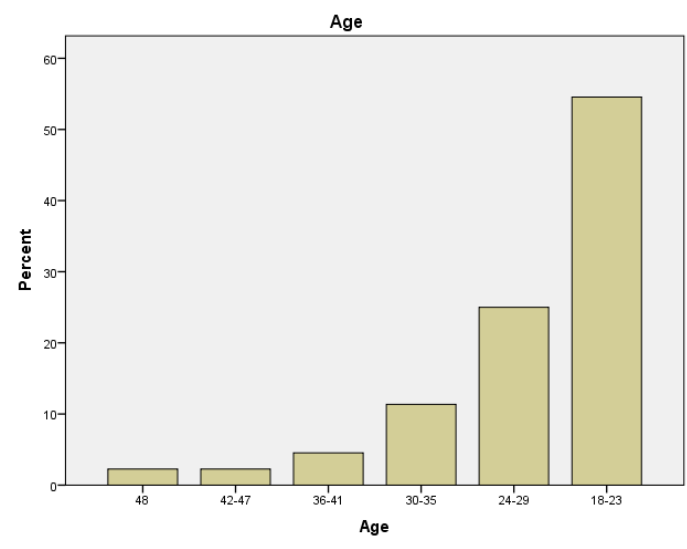

Figure 2: Age ranges of teacher trainees

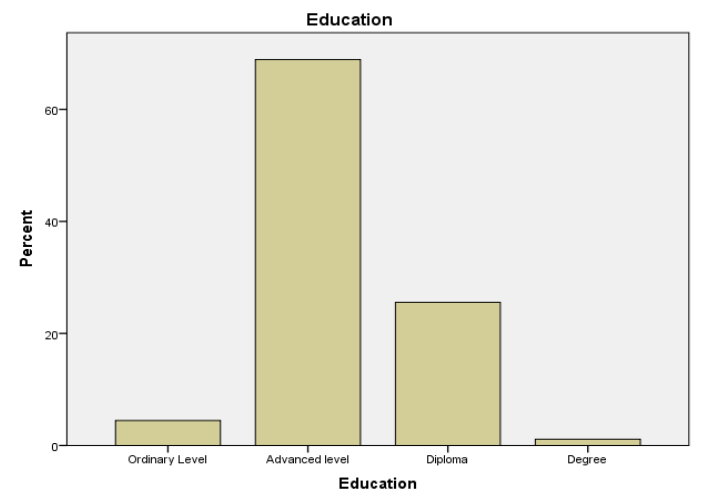

Figure 3 : Education levels

However, there is no significant relationship between education and performance. Although the tertiary authority uses online platforms, the findings of the study revealed that the institute faces constant challenges due to procrastination practices and bureaucratic procedures. Furthermore, institute struggles with the supervision of teaching practice.

Study discovered that $38 \%$ trainees mentioned learning teaching process to be improved by regular evaluation while $22 \%$ said they need revision and $11 \%$ stated need to use multimedia frequently.

\section{CONCLUSION}

The study concluded that there are more female teacher trainees compared male and their performance is in good level though $38 \%$ trainees emphasized that performance can be improved 
through regular evaluation. $87 \%$ trainees stated that registration of their diploma at the tertiary authority motivated them to enroll at the institute though the impact of the said authority low on learning teaching process of Teacher Education diplomas.

\section{REFERENCES}

[1] Dharmadasa,K.,H., Dharmadasa, I., Gunawardane, R., (1996) Sri Lankan Teachers' Development, Retrieved December 04, 2020 from https://files.eric.ed.gov/fulltext/ED405310.pdf

[2 Edirisinghe, N., Thusharika, H.,K.,N., \&Damayanthi, P.G.R. (2016) Impact on trainer training programme on teaching and learning process in Technical Colleges and Vocational training centres in Sri Lanka. Sri Lanka :TVEC

[3] Edirisinghe, S.,M.(2016). Research Study on Effectiveness of Vocational Training Programmes Conducted by National Vocational Training Institute Narahenpita. Sri Lanka: TVEC

[4] Jocelyne, M.S. (2014). Recruitment Practices and Performance of Administrative staff at MasindeMuliro University of Science and Technology, Kenya. Unpublished master's thesis, University of Nairobi, School of Business.

[5] Johnson, D. (2006). Investing in Teacher Effectiveness to Improve Educational Quality in Developing Countries: Does in-Service Education for Primary Mathematics Teachers in Sri Lanka Make a Difference to Teaching and Learning? Retrieved December 04, 2020 from https://oi.org/10.2304/rcie.2006.1.1.7

[6] Lekamge G., D., Irugalbandara, A.,Y., Fernando M.,N.,C. (2018). Analysis of the Problems of and the Suitable Solutions for an Initial Teacher Training Programme Conducted through the Distance Mode, OUSL Journal Vol. 13, No. 01 (pp. 115-133), Retrieved December 04, 2020 from http://doi.org/10.4038/ouslj.v13i1.7428

[7] Ministry of Skills Development and Vocational Training. Retrieved 12, February 2019 from www.skillsmin.gov.lk/institutes/tvec

[8] Nanayakkara, G.,L.,S., Neumann,K.,D., Pohlenz, P. (2006). Quality Assurance in Sri Lankan Teacher Training Evaluation Procedures for the Assessment of the Internship Period, Retrieved December 02, 2020 from https://www.researchgate.net/publication/237723432_Quality_Assurance i n_Sri_Lankan_Teacher_Training_Evaluation_Procedures for the Assessm ent of the Internship Period

[9] National Education Commission (2016). Study on the professional development of teachers and teacher educators in Sri Lanka. National Education Commission, Sri Lanka

[10] Polgampala, S. (2020). Kahoot conquers the highest peaks in the classroom through interest and attention': Using the Kahoot game-based learning platform to enhance teacher education, Retrieved December 04, 2020 from https://www.researchgate.net/publication/339602605_Sri_Lanka_English_L anguage_Teacher_Educator_Conference

[11] Rahaman, F., Jumani, N.B., Akhter, Y., Chisthi, S.H., \& Ajmal, H. (2011). Relationship between Training of Teachers and Effectiveness of Teaching. International Journal of Business and Social Sciences, 2(4)pp.150-160.

[12] Tatto, M. \& Kularatne N.G.(1993). The interpersonal dimension of teacher education: Comparing distance education with two other programmes in Sri Lanka. International journal of Educational Research, 19(8), pp.755-778.
[13] Thomas, L (2020). An Introduction to Simple Random Sampling, Retrieved December 04, 2020 from https://www.scribbr.com/methodology/simple-random-sampling/

[14] UNESCO. Retrieved 11,February 2019 from uis.unesco.org

[15] Weelahan, L. (2010). Literature Review: quality of teaching in VET. Melbourne: University of Melbourne

[16] Wettewa,V.(2016).Postcolonial emotionalism in shaping education: An Analysis of School choice in Sri Lanka. The International Education Journal, 15(1) 2016 pp.66-83.

[17]Wewegama W.M.M.R. (n.d.). Empowering the pre-service teacher candidates to teach children with special education needs in an inclusive English language classroom. Mahaweli National College of Education, Retrieved December 04, 2020 from http://43.224.127.162/moe/images/Branchnews/research/res.pdf 